This article has been published in a revised form in History in Africa, 47. pp. 101-118.

https://doi.org/10.1017/hia.2019.26

This version is published under a Creative Commons CC-BY-NC-ND. No commercial re-distribution or re-use allowed. Derivative works cannot be distributed. (C) African Studies Association 2019

Accepted version downloaded from SOAS Research Online: http://eprints.soas.ac.uk/34231

\title{
Archives, the Digital Turn and Governance in Africa
}

Fabienne Chamelot

$\mathrm{PhD}$ candidate

University of Portsmouth

School of Area Studies, History, Politics and Literature

Park Building

King Henry I Street

Portsmouth PO1 2DZ

United Kingdom

$+44(0) 7927412143$

fabienne.chamelot@port.ac.uk

Dr Vincent Hiribaren

Senior Lecturer in Modern African History

History Department

King's College London

Strand

London,

WC2R 2LS

United Kingdom 
vincent.hiribarren@kcl.ac.uk

Dr Marie Rodet

Senior Lecturer in the History of Africa

SOAS University of London

School of History, Philosophies and Religion Studies

10 Thornhaugh Street

Russell Square

London WC1H 0XG

United Kingdom

+44 (0)2078984606

mr28@soas.ac.uk 
Acknowledgments:

The authors would like to thank Yann Potin, along with the scholars who kindly suggested changes to our introduction at the European Conference of African Studies (2019) and those who agreed to participate in the peer-review process. 
This manuscript has not been previously published and is not under review for publication elsewhere. 
Fabienne Chamelot is a PhD student at the University of Portsmouth. Her research explores the making of colonial archives in the 20th century, with French West Africa and the Indochinese Union as its specific focus. She has an MA in Social Sciences from the Ecole des hautes études en sciences sociales and the Ecole normale supérieure in Paris. Before embarking on her PhD she worked in non-fiction publishing in France.

Dr Vincent Hiribarren is Senior Lecturer in Modern African History at King's College London. He is the author of two books on the history of Borno, a region in north-eastern Nigeria (A History of Borno, Hurst and Oxford University Press, 2017 and Un manguier au Nigeria, Plon, Terre Humaine, 2019). Interested in Digital Humanities, he has obtained three grants from the British Library 'Endangered Archives Programme' and is on the board of the UCLA 'Documenting Global Voices' programme. Of interest too is the blog he has been co-editing for the French newspaper Libération since 2014 http://libeafrica4.blogs.liberation.fr/. His personal website is at: http://www.vincenthiribarren.com/

Dr Marie Rodet is Senior Lecturer in the History of Africa at SOAS University of London. Her research interests lie in the field of migration history, gender studies and the history of slavery in West Africa in the nineteenth and twentieth centuries. Her monograph, published by Karthala (Paris 2009), reintegrates women into the narrative of modern African migration history. Her research for the past five years has focused on emancipation processes in the context of the ending of slavery in Mali and Senegal. In 2014 she edited a documentary film recounting the history of the "Diambourou" communities of formerly enslaved populations in Kayes, Mali, who fought for their freedom during the first half of the twentieth century. As a continuation of 
that documentary she is currently working on her second monograph on slave resistance in Kayes (1890-1940). From 2008 to 2010 she managed a project to salvage archival materials in Mali covering 100 years of its history. The project saw the cooperation of the Malian Ministry of Territorial Affairs, the French Embassy in Mali and the authorities of the District of Kayes, and for four months during it she trained ten Malian assistant archivists in Kayes. In 2016 she initiated a similar pilot project with the support of the British Library Endangered Programme to digitize archives in Kita, Mali. In 2018 she secured a BL major grant to digitize the entire colonial collection (1889-1960). 


\begin{abstract}
Archives, the Digital Turn and Governance in Africa

With the rise of information technology, an increasing proportion of public African archives are being digitised and made accessible on the internet. The same is being done to a certain extent with private archives too. As much as the new technologies are raising enthusiasm, they have prompted discussion among researchers and archivists, on subjects ranging from matters of intellectual property to sovereignty and governance. Digital archiving disrupts archival norms and practices, opening up a field of reflection relatively little explored by historians. This article therefore seeks to reflect on the digital turn of African archives as a subject for study in its own right, located at the crossroads of political and economic interests.
\end{abstract}

\title{
Archives, tournant numérique et gouvernance en Afrique
}

Avec l'essor des technologies de l'information, de plus en plus d'archives africaines publiques (et dans une certaine mesure privées) sont numérisées et rendues accessibles sur Internet. Même si ces nouvelles technologies suscitent l'enthousiasme, elles génèrent également des discussions entre chercheurs et archivistes, qui vont de la propriété intellectuelle à la souveraineté en passant par la gouvernance. L'archivage numérique perturbe les normes et les pratiques archivistiques et conséquemment ouvre un champ de réflexion relativement peu exploré par les historiens. Cet article cherche à offrir une réflexion sur le virage numérique pris par les archives africaines en le considérant comme un objet d'étude à part entière situé au carrefour d'intérêts politiques et économiques. 
As information technology has become more significant, steadily more African archives, both public and — at least to an extent — private ones, are being put into digital formats and made accessible on the internet. The gathering wave of digitisation is usually seen as progress, as ambitious initiatives help to apply new technologies to cultural heritage, such as the rescue of the manuscripts of Timbuktu or the Endangered Archives programme at the British Library. Yet as much as the new technologies have raised enthusiasm, they have caused debate too among researchers and archivists, who are having to address concerns about intellectual property rights, and things like sovereignty and governance.

The digitisation of archives has opened technical opportunities to negotiate tension between African and European countries on matters related to colonial archives, their ownership and legacy. The questions relate to the challenges of "shared memory" and "shared history" as well as to "decolonisation", 1 or at any rate that has been the rationale for the presentation of digital copies on the international political scene and in various media. As an example, digitisation has meant that the colonial archives kept in the Museum of Tervuren in Belgium might now be given back to the Rwandese government, ${ }^{2}$ while in 2014 a digitised copy of the records of the 1944 massacre in Thiaroye could be presented to Macky Sall, President of Senegal, by then French President François Hollande. ${ }^{3}$ However, such initiatives do not go

\footnotetext{
${ }^{1}$ Imorou, Abdoulaye, "Thiaroye, Oradour-sur-Glane et les défis d'une mémoire partagée. Une lecture croisée de Camp Thiaroye et du Vieux Fusil." Études littéraires africaines, 40 (2015), 61-76; Mbaye, Osmane, "Le CAOM: Un Centre d'archives Partagées?" Afrique \& Histoire 1-7 (2009): 291-299; Lagae, John, "From 'Patrimoine partagé' to 'whose heritage'? Critical Reflections on colonial built heritage in the city of Lubumbashi, Democratic Republic of the Congo", Afrika Focus 21-1 (2008): 11-30.

2 "La Belgique va rendre au Rwanda les archives de la période coloniale," RTBF.be, 8 September 2018 (accessed 7 February 2019). https://www.rtbf.be/info/belgique/detail la-belgique-va-rendre-au-rwanda-les-archives-de-laperiode-coloniale? $\mathrm{id}=10031374$

${ }^{3}$ Moure, Martin, "Thiaroye 1944. Histoire et mémoire d'un massacre", Africa4, Libération, 16 August 2017 (accessed 7 February 2019). http://libeafrica4.blogs.liberation.fr/2017/08/16/thiaroye-1944-histoire-et-memoiredun-massacre/
} 
without controversy and debate, ${ }^{4}$ which shows that beyond the strict technical aspects, archives carry with them their share of political issues. In that sense, debates over digitisation are to be understood as a continuation of long-running problems and controversies over archives, notably colonial archives and microfilming. ${ }^{5}$

At the same time, expectations are great among scholars who might see the overall digitisation process as an opportunity to "dematerialise" access to archives and to lay firmer hold on their sources without always exploring the implications and complexity of such a process as applied to archives. The focus in scholarly debates more often revolves around the production of knowledge and the reliability, or 'truth', of sources, and while those aspects are essential to contemporary research, the whole subject of the politics of the making of conventional archives — let alone that of digitised ones — is less often addressed.

The first point to make, in the digital era, is that the question of ownership of documents is a crucial one, since the very definition of archive is challenged. The unique "hard copies" of paper documents can now exist in a variety of formats potentially reproducible at will. New possibilities have arisen for potential partnerships, and those possibilities bring their own challenges with them in terms of access and accountability. Secondly, various technical and economic matters at stake are equally essential to the discussion and are intertwined with the matter of sovereignty. African institutions elaborating a digitisation programme might be doing so at the initiative of donors or non-African scholars, so that such archives are affected by negotiations that go far beyond the simple technical and scientific aspects.

\footnotetext{
4 Trouillard, Stéphanie, "Massacre de Thiaroye: 70 ans après, les zones d'ombre demeurent," France24.com, 1 December 2014 (accessed 7 February 2019). https://www.france24.com/fr/20141128-massacre-thiaroyecommemoration-senegal-dakar-tirailleurs-armee-france-polemique-historien; "Massacre de Thiaroye en 1944: A quand la fin de l'obstruction à la manifestation de la vérité ?" Le Monde Afrique, 1 December 2016 (accessed 7 February 2019). https://www.lemonde.fr/afrique/article/2016/12/01/massacre-de-thiaroye-en-1944-a-quand-la-finde-l-obstruction-a-la-manifestation-de-la-verite $5041553 \quad 3212 . \mathrm{html}$

${ }_{5}$ Bat, Jean-Pierre, "Les Archives de l'AEF", Afrique \& Histoire 1, no. 7 (2009), 301-311; Shepard, Todd, “'Of Sovereignty': Disputed Archives, 'Wholly Modern' Archives, and the Post-Decolonization French and Algerian Republics, 1962-2012”, American Historical Review 120, no. 3 (June 2015), 869-883; Mnjama, Nathan, and James Lowry, "A Proposal for Action on African Archives in Europe", in: James Lowry (ed.), Displaced Archives (London: Routledge, 2017), 101-113; Hiribarren, Vincent, "Hiding the Colonial Past, A Comparison of European Archival Policies", in: James Lowry (ed), Displaced Archives (London: Routledge, 2017).
} 
In the field of history, archives are usually addressed as sources for research and are questioned as such because of their documentary and historical aspects. More rarely are they approached as historically constructed systems combining intellectual and physical dimensions in the way archival science theorises them. Digital archiving therefore disrupts archival norms and practices, so opening up a field of reflection relatively little explored by historians. The digital turn of African archives is therefore an object of study in its own right, standing at the crossroads of political and economic interests.

In addressing the wave of digitisation of archives in Africa over the last fifteen years, this featured section of History in Africa therefore seeks to reflect on the practices of digitisation of archives in Africa and to engage with both history and archival science.

A remarkable enthusiasm for archives as an object of study has kept many scholars busy in the last decades, scholars from a wide range of disciplines in the humanities, from philosophy to the arts. Numerous academic debates and discussions on archives have been prompted in the light of Foucault's The Archeology of Knowledge ${ }^{6}$ and Derrida's Archive Fever', and postmodernism more generally. Indeed, the "archival turn" in cultural studies has recently stretched the meaning of the word "archive" and shifted "archives as concrete places to archives as more abstract- but just as real - conditions of knowledge". ${ }^{8}$ From that perspective the concept of "archive" (in the singular) seems to be able not only to encapsulate a variety of objects and entities such as oceans for example, but could also be "performed". ${ }^{9}$ Nevertheless, Michelle Caswell reminds us that "the archive is not an archives", and that work and research from the

\footnotetext{
${ }^{6}$ Foucault, Michel, The Archeology of Knowledge (London: Tavistock, 1972).

7 Derrida, Jacques [trans. by Eric Prenowitz], Archive Fever: A Freudian Impression (Chicago: University of Chicago Press, 1996).

${ }^{8}$ Paprikka, Jussi, "Archival media theory. An introduction to Wolfgang Ernst's media archaeology", in: Wolfgang Ernst, Digital memory and the archives (Minneapolis, London: University of Minnesota Press, 2013), 4.

${ }^{9}$ Mawani, Renisa, "Archival Legal History. Towards the Ocean as Archive," in: Markus D. Dubber and Christopher Tomlins (eds), Oxford Handbook of Legal History (Oxford: Oxford University Press, 2018), 291-310; Le Lay, Maëline, "Performer l'archive pour réécrire l'histoire: l'exposition Congo Far West au Musée royal de l'Afrique centrale de Tervuren", in: Maëline Le Lay, Dominique Malaquais and Nadine Siegert (eds), Archive (re)mix. Vues d'Afrique (Paris: Presses Universitaires de Rennes, 2015), 107-123.
} 
field of archival studies are often omitted from recent scholarship on archives. ${ }^{10}$ The very word "Archive" has come to be used to describe an all-encompassing notion, and in the process has perhaps lost some of its clarity, to the point that Kate Theimer argued in 2014 that confusion exists between the term "archives" and what could simply be called "historical representation" based on a selection of documents from the past. ${ }^{11}$ As a result, the term "archives" now tends to be vaguely defined and is often overused in relation to legacy, narrative and knowledge.

However, or maybe for that reason, the echo of postmodernism in the field of archival science and some of the debates over it contrasted one another. ${ }^{12}$ As stated by Rachel Hardiman, "Although postmodernist ideas have their origins in fields external to the recordkeeping world, their impact and pervasiveness is such that, accepted or rejected, they cannot be simply ignored". ${ }^{13}$ The postmodernist critique, when specifically directed at the production of knowledge and historiography and especially but not only in relation to Africa, has uncovered the limits of a "positivist" approach to knowledge and demonstrated the relevance of examining and re-examining the making of archives as well as of history. "Archives" have themselves become a subject of study going beyond the professional activities of archivists and historians. Antoinette Burton, for example, has written about evidence, narrative and the archive. ${ }^{14}$ Anthropologists like Ann Laura Stoler have begun to use archives in their own research and have theorised their use. ${ }^{15}$ Many researchers have engaged with the subject and have produced

\footnotetext{
${ }^{10}$ Caswell, ML, “'The archives' is not an archives: on acknowledging the intellectual contributions of archival studies”, Reconstruction 16(1), 10-11.

${ }^{11}$ Theimer, Kate, "A Distinction Worth Exploring: 'Archives' and 'Digital Historical Representations"', Journal of Digital Humanities, 2014 (accessed 20 December 2018). http://journalofdigitalhumanities.org/3-2/a-distinctionworth-exploring-archives-and-digital-historical-representations/

$\frac{12}{12}$ For an article providing a comprehensive summary of the postmodernist debate within the archive science community as well as an extensive bibliographic reference list, see: Cook, Terry, "Archival science and postmodernism: new formulations for old concepts," Archival Science 1-1 (2001), 3-24.

${ }^{13}$ Hardiman, Rachel, "En Mal d'archive: Postmodernist Theory and Record Keeping," Journal of the Society of Archivists 30, 1 (April 2009), 27-44.

${ }^{14}$ Burton, Antoinette M., Archive Stories: Facts, Fictions, and the Writing of History (Durham, N.C.: Duke University Press, 2005).

${ }^{15}$ Stoler, Ann Laura, "Colonial Archives and the Arts of Governance: On the Content in the Form", in: Francis X Blouin and William G Rosenberg (eds.), Archives, Documentation, and Institutions of Social Memory Essays from the Sawyer Seminar (Ann Arbor: University of Michigan Press, 2007), 267-279.
} 
thought-provoking works about the articulation between colonial narrative and archives. ${ }^{16}$ Archivists themselves of course, explore the topic and are able to further the theoretical reflection from their concrete, practical perspective. ${ }^{17}$

The works of those writers, and the whole field more broadly, are essential to the examination of the production of knowledge. Such writers focus on content and narrative, and therefore engage with archives as documents. Yet another notion, often overlooked by historians, defines archives as the fonds, which is the basic unit for their classification rather than documents or records. When designing classification systems, archivists work to identify and bring to light the function of the governing body that produced a given document, and they consider that function within its larger administrative framework. In short, they seek the "why" of the documents and not the "what". Anyone might file documents in a specific and personally suitable manner, depending perhaps on equipment, habits of work, or some particular approach. In the same way, a governing body will order documents in a way specific to its own organisation and rationale.

That is an essential feature of archives and understanding it is crucial to being able to grasp the difference between archival science and library and information science:

"An archival collection is an organic whole, a living organism, which grows, takes shape, and undergoes changes in accordance with rules. If the functions of the body change, the nature of the archival collection changes likewise. The rules which govern the composition, the arrangement and the formation of an archival collection, therefore, cannot be fixed by the archivist in advance; he can only study the organism and ascertain the rules under which it was

\footnotetext{
${ }^{16}$ To name a small selection: Busia, Abena P. A., "Creating the Archive of African Women's Writing: Reflecting on Feminism, Epistemology, and the Women Writing Africa Project", Meridians 17 (2) (November 2018), 233245; El-Malik, Shiera S. and Kamola, Isaac. A (eds), Politics of African Anticolonial Archives (London, New York: Rowman \& Littlefield, 2017); Bakare-Yusuf, Bibi, Archival Fever, Dipsaus podcast, 30 December 2018 (accessed on 7 February 2018. https://www.dipsaus.org/exclusives-posts/2018/12/29/ihbijoa397wfc7xsghodvlr216wlvn

${ }^{17}$ See Ndeshi Namhila, Ellen, "Content and use of colonial archives: an under-researched issue", Archival Science 16 (2016), 111-123; Ndeshi Namhila, Ellen, "Archives of Anto-Colonial Resistance and the Liberation Struggle (AACRLS): An integrated programme to fill the colonial gaps in the archival record of Namibia", Journal for Studies in Humanities and Social Sciences 4(1-2) (2015), 168-178.
} 
formed. Every archival collection has, therefore, as it were, its own personality, its individuality, which the archivist must become acquainted with before he can proceed to its arrangement."18

That definition of archives is not intended to mean that archival stewardship is by any means neutral. ${ }^{19}$ However, it does imply that an archive is as much a structure as a gathering of documents. The digital turn that archives are taking is therefore of huge significance because it might affect the nature of the fonds as well as their arrangement. It is in fact a reflection of a broader shift in structures of power and governing dynamics.

With that in mind, we can see that the process of digitisation therefore consists not simply of making digital copies of paper documents, for it is more than "digital photocopying". Rather, the whole structure of any archive ought to be preserved and conveyed so as to reflect the rationale of the administration that created it. Such information is essential to the historical contextualisation of sources and to understand the structures of power and governance.

That is even more true of the African case. There, many countries have developed archive institutions only relatively recently and certain of those have moved directly to "digital archives" without necessarily converting existing material, practices and processes from paper to a digital format. In other cases on the African continent digitization processes have been designed not only to classify but to "salvage" numerous endangered documents. The making of a detailed and hierarchically arranged listing of documents to be digitalised might then be favoured at the expense of preserving the fonds and structure of that archive. From that perspective the metadata of the archive can potentially become de facto an archival index with the attendant risk that basic archival standards such as provenance and respect des fonds (original order) are lost in the process.

\footnotetext{
${ }^{18}$ Muller, Samuel, Feith Johan, A., Fruin, Robert, Manual for the Arrangement and description of Archives (New York: H.W. Wilson 1940), 19.

${ }^{19}$ Kim, Katherine, “'Archives have never been neutral': An NDSA interview with Jarrett Drake”, DLF, 15 February 2017 (accessed on 7 February 2019). https:/www.diglib.org/archives-have-never-been-neutral-an-ndsa-interviewwith-jarrett-drake/; Blouin, Francis X. Jr and Rosenberg, William G. (eds), Archives, Documentation, and Institutions of Social Memory (Ann Arbor: The University of Michigan Press, 2005), 87.
} 
The making of metadata is certainly accompanied by its share of challenges. As a structuring norm metadata tends to follow standards which might not always meet the structure of the fonds and might be dictated by the requirements of computer programming. For example, it might not always be possible to apply AToM standards to African archives created in the first half of the twentieth century even if the International Council of Archives, as the body responsible for the creation of the international $\operatorname{ISAD}(\mathrm{G})$ norms, was the first to support AToM. ${ }^{20}$. Moreover, because it is in many instances incomplete, digitisation of existing archives tends to flatten a classification process which might actually have taken months or even years to create.

By privileging a loose definition of "archives" as being mainly an index of documents/items/artefacts rather than a constituted fonds, the importance of the physical structure in the making of archives can come to be overlooked. That can in turn put at risk the long-term preservation of the physical fonds, jeopardizing the information and knowledge it conveys about the governing body or entity that produced it.

The shift from paper to digital formats does not therefore consist solely of technicalities, although it certainly represents an epistemic "digital turn" in the history of archival practices and usage. First, the volume of and even the very structure of digital sources and data raise questions about the legitimacy and neutrality of the management of archives. Secondly, it consists in a reflection of the reconfiguration of worldwide power dynamics on the local and the global scales. In a "dematerialised" world, how can archives be controlled, both as part of a legacy but also as a record of the tools of government? Third, while the potential of unlimited access to sources by the public all over the world creates numerous opportunities, those very opportunities are accompanied by ethical and methodological problems.

${ }^{20}$ AToM is a web-based archive description norm, $\operatorname{ASAD}(\mathrm{G})$ is the paper-based one. 
As a consequence, the current wave of digitisation is also radically changing the nature of research for scholars, archivists and governments. Scholars can now read documents without the cost of travelling to different archive centres and are able therefore to produce research results based on "remote African" documents. At the time of writing this introduction, examples are countless, but it is worth mentioning that since the 1960s many documents have been duplicated by means of the microfilming of entire collections by universities - such as Syracuse University $^{21}$ — or by governments. However, the digitisation and the subsequent uploading of considerable amounts of data to servers has made large amounts of material available virtually everywhere on the planet, at least to institutions or individuals who can afford an Internet connection. The pioneers were the Digital Imaging South Africa team (DISA) at the University of KwaZulu-Natal in Durban in South Africa in 2002. Funded by the Andrew Mellon foundation, the project's aim was to digitize periodicals concerned with the anti-apartheid struggle in South Africa from 1960 to 1994. DISA also inaugurated a pattern which is still recognisable fifteen years later where a Northern institution, or in the case of the Andrew Mellon foundation a private foundation, provides funds for a digitisation project actually based in Africa. "Aluka" is an online platform created in 2003 on the same model, to gather documents on the liberation struggles of southern Africa during the second half of the twentieth century. ${ }^{22}$ Funded initially by the US Mellon, Hewlett, and Niarchos private foundations it became an important archival repository before being integrated into JSTOR in $2008 .{ }^{23}$ Incidentally both Aluka and JSTOR are sub-branches of the not-for-profit Ithaka organisation, also a US initiative. Aluka specifically became one of the first collaborative platforms whereby archivists and researchers tried to develop a new narrative of the recently-won battles for liberation. Indeed it

\footnotetext{
${ }^{21}$ Syracuse University microfilmed most of the archives hosted by the National Archives of Kenya in the 1960s https://surface.syr.edu/archiveguidekenya/9/ (accessed 11 April 2019).

${ }^{22}$ Isaacman, Allen, Premesh Lalu, and Thomas Nygren, "Digitization, History, and the Making of a Postcolonial Archive of Southern African Liberation Struggles the Aluka Project", Africa Today, 52 (2005), 55-77.

23 https://about.jstor.org/whats-in-jstor/primary-sources/struggles-freedom-southern-africa/partnerships/ (accessed 15 January 2018). See also Ryan, Deirdre, "Aluka: Digitization from Maputo to Timbuktu", OCLC Systems \& Services, 26 (2010), 29-38.
} 
was no coincidence that all those projects were hosted in South Africa and the publication in 2002 of Refiguring the Archive illustrates the phenomenon particularly well. ${ }^{24}$ Peter Limb, a scholar of South Africa, was among the first to develop a critical understanding of that first wave of digitization and all his publications show that his original insight was accurate: "Twenty-first century missionaries carry not Bibles but scanners". ${ }^{25}$

The hope of this featured section of History in Africa is at least to further the debate. The last twenty years have witnessed the multiplication of digitisation programmes in Africa. ${ }^{26}$ Many projects are now available online despite their being difficult to find via most search engines. Because there are so many it would be nearly impossible to draw up a full list of all the projects undertaken by charities like the Mormons, universities, ${ }^{27}$ governments (French “cooperation”), private companies like Arkhênum and Google ${ }^{28}$ - or individuals. ${ }^{29}$. In response to calls from international Northern institutions like Blue Shield, Archivistes Sans Frontières - International, British Library Endangered Archives Programme; ${ }^{30}$ the Foundation Mário Suarez, the Prince Claus fund ${ }^{31}$ orModern Endangered Archives Programme, ${ }^{32}$ since the beginning of the $21^{\text {st }}$ century archivists and historians have embraced digital solutions to preserve documents in their

\footnotetext{
${ }^{24}$ Premesh, Lalu, "The Virtual Stampede for Africa: Digitisation, Postcoloniality and Archives of the Liberation Struggles in Southern Africa", Innovation, 34 (2007), 28-44 or Breckenridge, Keith, "The Politics of the Parallel Archive: Digital Imperialism and the Future of Record-Keeping in the Age of Digital Reproduction", Journal of Southern African Studies, 40 (2014), 499-519.

${ }^{25}$ Limb, Peter, 'The Politics of Digital "Reform and Revolution" towards Mainstreaming and African Control of African Digitisation', Innovation, 34.1 (2007), 18-27 (23). See also Limb, Peter, 'The Digitization of Africa', Africa Today, 52.2 (2005), 3-19.

${ }^{26}$ Delva, Jean-Pierre, "Un autre regard sur les archives en Afrique”, Comma, 2015 (2016), 113-118.

${ }^{27}$ See the tremendous work done by Derek Peterson over the years in Uganda: https://derekrpeterson.com/archivework/ (accessed 4 November 2018). See also Taylor, Edgar, Ashley Rockenbach, and Natalie Bond, "Archives and the Past: Cataloguing and Digitisation in Uganda's Archives", in: Terry Barringer and Marion Wallace (eds.), Dis/Connects: African Studies in the Digital Age (Leiden: Brill, 2014), 163-178.

${ }^{28}$ In 2015, Google launched a programme of digitization of cultural artefacts, including archives, with the Kenya National Archives: https://artsandculture.google.com/partner/kenya-national-archives (accessed 20 June 2019).

${ }^{29}$ Martino, Enrique, "Open Sourcing the Colonial Archive - A Digital Montage of the History of Fernando Pó and the Bight of Biafra", History in Africa, 14 (2014), 387-415.

${ }^{30}$ https://eap.bl.uk/ (accessed 23 January 2019). Two co-authors of this introduction (Marie Rodet and Vincent Hiribarren) have obtained major grants from the British Library. Butterworth, Jody, "Saving Archives through Digitisation: Reflections on Endangered Archives Programme in Africa”, SCOLMA, 2017, 2-14.

31 https://princeclausfund.org/we-are (accessed 23 January 2019) is funded by the "Dutch Ministry of Foreign Affairs, the Dutch Postcode Lottery, and private individuals and corporations".

32 https://www.library.ucla.edu/partnerships/modern-endangered-archives-program (accessed 15 September 2019). A co-author of this introduction (Vincent Hiribarren) is a member of the international board of 'Modern Endangered Archives Programme' (UCLA) funded by Arcadia.
} 
areas of expertise. Admittedly, Africa is not the only continent on which digitisation programmes have taken place, but it is worth noting that African archives have been disappearing at an alarming rate not only because of political factors but climatic ones too. Consequently, a very large share of the money invested in digitisation has been spent on programmes actually in Africa.

The phenomenon may be partially explained by technological advances, in the first instance. Inversely following Moore's Law which predicted that the number of transistors in an integrated circuit would double every two years, the price of the IT equipment necessary to undertake digitisation programmes has fallen dramatically. Digital cameras for example have become much more affordable and in certain application have replaced cumbersome scanners. More crucially, hard drives, on which thousands of files of professional quality may now be stored, are considerably cheaper than they were in the 2000 s as are Internet connections. Largescale digitisation programmes are therefore now increasingly feasible using relatively smaller amounts of money. One collateral symptom of the technological evolution is that many scholars have been able to store on hard drives many gigabytes of photographs of archives taken in Africa using their mobile telephone cameras. One could argue that the often un-coordinated efforts of massive digitisation projects extend the concept of an "archive" so that virtual and dispersed collection as in the case of "anticolonial archives" may be genuinely labelled "archives". ${ }^{33}$

Finally, there is still the widespread positivist belief that holds science - in this case digitisation - to be the solution to all the problems faced by historians, archivists or governments. Furthermore, the "complex of the white saviour" seems sometimes to have been turned into the "complex of the digital saviour" in a humanitarian African context, as so many Northern governments, institutions or individuals have wished to join hands with African

\footnotetext{
${ }^{33}$ El-Malik, Shiera S., and Isaac A. Kamola (eds.), Politics of African Anticolonial Archive (London: Rowman \& Littlefield, 2017).
} 
archivists to work on digitisation projects. ${ }^{34}$ There again, the idea of Western science being a panacea for the problems of development and governance faced by the African continent, is far from new.

The Church of Jesus Christ of Latter-day Saints — better known as the Mormon Church — has assumed responsibility for the microfilming and digitisation of birth and death registers in numerous African countries. ${ }^{35}$ In their case the "saviour complex" is explicitly Christian and based on the belief that the dead may be baptised in order to 'redeem' and 'save' any who die 'with no knowledge of Jesus'. ${ }^{36}$ While the number of documents digitised by the Mormon Church remains unclear, their genealogy database FamilySearch contains data obtained from thousands of documents digitised in Africa. ${ }^{37}$

The 2010s were the decade when the "complex of the digital saviour" affected historians and archivists most spectacularly. Conflict-ridden regions have become archetypal places where traces of the past need to be preserved. A striking example is Mali, where historians-cumsaviours have digitised manuscripts from Timbuktu. Captured in 2012 by members of Ansar Dine and the National Movement for the Liberation of Azawad, Timbuktu has become the reluctant symbol of African culture under attack by jihadist obscurantists. The need for Timbuktu's manuscripts to be saved was not new and had actually been at the origin of the creation of the Ahmed Baba national archives in Timbuktu. However, the crisis of 2012 in Mali added new urgency to the situation. New private archive entrepreneurs saw an opportunity to place under the spotlight a series of mostly private emergency rescue and digitisation projects, which required enormous and urgent worldwide fundraising campaigns.

\footnotetext{
${ }^{34}$ Shringarpure, Bhakti, 'Africa and the Digital Savior Complex', Journal of African Cultural Studies, 0 (2018), 117.

${ }^{35}$ See an example in Sierra Leone. https://newsroom.churchofjesuschrist.org/article/church-preserves-preciousrecords-of-african-nation (accessed 20 June 2019).

${ }^{36} \mathrm{https}$ ://www.churchofjesuschrist.org/study/new-era/2017/08/why-baptisms-for-the-dead?lang=eng (accessed 20 June 2019).

${ }^{37}$ https://www.familysearch.org/search/collection/list/?page=1\&recordType=Migration\&ec=region\%3AAFRICA (accessed 20 June 2019).
} 
Strikingly, the sustainability of such large-scale digital projects is not always thoroughly considered. Terabytes of data are now held on hard drives and to a lesser extent on memory sticks and DVDs. Hard drives (external Solid State Drives) are usually designed to survive for 10 years if they are used as cold storage. Funding bodies in many Western countries actually ask their successful candidates to provide a data management plan to manage data files in the immediate future but no one yet knows how to preserve digital data for much longer times without constantly duplicating it. Surely it is far from fanciful even now to think of future projects being needed to save endangered digital files, perhaps in just a few decades? After all, in many archive centres today microfilms are urgently being digitised.

Already accused of fetishizing written documents even in an African context, many historians appropriated the discourse on "endangered archives". They have chosen to save "their" archives, sometimes joining forces with private archiving entrepreneurs while dismissing the role played by professional archivists working in the public sector. The trend of private initiatives can prove extremely problematic when historians disregard what archivists have previously done or are currently doing to preserve the documents in question - even if more slowly and within a national institutional framework. In the French context Yann Potin has already explored the "divorce" between historians and archivists and stressed that most historians ignore what archivists have accomplished in creating, classifying, cataloguing and preserving "their" archives. ${ }^{38}$ Such ignorance of the archivist's work is often exacerbated by the fact that some digitisation projects have dealt only vaguely with historical "archives," such projects certainly tending to reinforce a form of disciplinary arrogance, as M. L. Caswell argued in 2016: "There seems to be little understanding in the humanities that professional archivists have master's degrees, that archival standards and best practices are culturally constructed

\footnotetext{
${ }^{38}$ Potin, Yann, “Intervention de Yann Potin”, Gazette des archives, 225 (2012), 49-53.
} 
artefacts, and that behind every act of archival practice is at least a century-old theoretical conversation." 39

The digital files we see on our computer screens give the false impression that the documents were discovered and 'harvested' easily, like large nuggets littering the floor of an archival gold mine. All the archival work undertaken before, during and after digitisation is being made invisible, as the term "archive" has come to designate not the physical documents any more, but what appears on the screen. Such obliteration, as it were, of the work of African archivists coupled with the "digital imperialism" already observed in the 2000s might yet have dramatic consequences for the future of African archives, which are already underfunded. Most current digitisation projects rely on money from Northern institutions, and they tend to focus on the final product, which of course is the digital material. Many if not most digitisation projects therefore concern archives which have already been classified and inventoried. As a noticeable result, only increasingly limited funding is being provided for what is practically needed to support the physical salvaging of genuinely endangered archives. Such things as acid-free paper, boxes, shelves, air conditioned rooms in suitable buildings, and so on are scarce, expensive and undervalued, it seems. There is now a greater risk that archives which have not been previously classified and inventoried will be lost because the slow work of digitisation projects monopolises the time of many archivists. There is then the very real prospect that the process of digitising will endanger not only the activities of archivists but to a certain extent even their very profession. In other words, Northern digital aspirations, with the complicity of Southern governments driven by short-term financial interests, might ruin longer-term Southern efforts at analogue preservation. Paradoxically all this will have been done in the name of enhancing good

\footnotetext{
${ }^{39}$ Caswell, M. L., "“'The Archive' Is Not an Archives: On Acknowledging the Intellectual Contributions of Archival Studies", Reconstruction: Studies in Contemporary Cultures, 16.1 (2016), p. 11 $<$ https://escholarship.org/uc/item/7bn4v1fk> [accessed 13 June 2019].
} 
governance in the South. ${ }^{40}$ When on top of that digitization programmes are conducted by private companies or 'heritage entrepreneurs' whose aim is financial profit, one can understand the sense of pillage being experienced by local populations and certain public experts in the sector. They are powerless to do more than deplore the increasing sub-contracting strategy of an under-resourced state. They can only deprecate neglectful or sometimes ill-intentioned politicians for whom archives are certainly not the priority, despite the fact that archives are a central public service, a state prerogative and a crucial government instrument which can ensure accountability and good governance.

\section{Structure and Content of this Special Issue}

Stockreiter's article clearly shows the potential of private partnerships between local initiatives and international heritage entrepreneurs when the state is absent, as in the case of the Djenné Manuscript Library. As such initiatives can be funded almost solely by external means (The British Library's Endangered Archives Programme in that case) their drawbacks are immediately obvious, with the risk that digitisation programmes will be ill-equipped to deal with local tensions and conflicting political interests, and will lack the necessary research experience to understand local contexts in order to secure access to the archives. Consequently there then arises the question of the outcome of the programme once the external heritage entrepreneurs and their funding have left. The inability of such projects to build digital sustainability and longterm development strategies is certainly one of the greatest limitations to the success of private partnerships driven from outside - if there will be no local and central government involvement in the long-term.

\footnotetext{
${ }^{40}$ For example, see Kargbo, John Abdul, "The Connection between Good Governance and Record Keeping: The Sierra Leone Experience", Journal of The Society of Archivists, 30 (2009), 249-260.
} 
Keese and Owabira's article is another that shows the limits of digitizing programmes which, as with many greatly endangered archives in Africa, tend to overlook the necessity of first salvaging physical archives many of which have never been classified nor even inventoried. There is in such cases an immediate risk of disappearance. For example, in the case of the postcolonial regional archives in Pointe Noire highlighted in this article, the number of files digitized is not a sufficient benchmark to assess the success of preserving similar such endangered archives. Cooperation between archivist and historian is here central to ensuring that the actual work done by archivists on the ground with very limited means does not suffer the endangerment which is always a possible side-effect of mostly externally driven digitization projects and "digital humanitarianism".

Schneider and Weinberg's article discusses directly and at length what constitutes the African photography archive and its contradictions, and how digitization might actually change the very nature of the photographs digitized. Increased accessibility globally might also and paradoxically accelerate the digital divide, as internet accessibility remains notably low in Africa. Who are the global audience, indeed? To whom are the digital contents made accessible? How can the whole dimension of a photograph be rendered in a digital collection? Which brings us back to the fundamental questions, 'What is an African photography digital archive?' and, 'To what extent does the digitization process disrupt archival norms, practices and definitions while as asserted by the authors "There is no way back!"?

El Qadim's article explores what a modern service of archives centred on digitization means and implies as in the case of the Archives du Maroc created in 2011. Has digitization become the new seal of approval for an archive to be considered modern in Africa? That is indubitably what the Archives du Maroc services claim and a central policy that they pursue at 
every level despite the onerous costs. But in a context of limited resources and while that institution is still in a fragile legitimation state, it is also probably a strategic "necessary evil" to secure more resources and funding in future.

Losch's article shows that the digitization processes targeting broadcasting archives at risk in West Africa since the beginning of the century have to do with pre-existing technical cooperation networks, which are themselves connected to colonial history. Losch also questions the practical implications for digitization in former French colonies in West Africa which do not retain digital copies of their oldest audio-visual heritage. The vast majority of that heritage is still in France, more specifically in the hands of its Institut National de l'Audiovisuel which has placed the material behind a pay wall. One consequence of that is an accrued postcolonial digital divide which has limited the national broadcasters' leeway, as in practice, safeguarding and preservation cannot be separated from the logics of restitution and sharing of already digitized audio-visual resources pertaining to a supposedly "shared" history.

Finally, Lawrance, Corcoran and Hooper's article more broadly questions the matter of "digital dispersal" of archives when that occurs simultaneously and haphazardly, whether accidentally or intentionally as in the case of asylum documentation. They consider what that implies for the archives of the future history of forced international migration as it applies to countries such as Togo. They refer again to questions about the dangers of digital documentation where there are no physical copies and the possible consequences of that situation for future access, and thus for transparency and ultimately its effect on governance. 


\section{References}

“Massacre de Thiaroye en 1944: A quand la fin de l'obstruction à la manifestation de la vérité ?" Le Monde Afrique, 1 December 2016 (accessed 7 February 2019). https://www.lemonde.fr/afrique/article/2016/12/01/massacre-de-thiaroye-en-1944-a-quand-lafin-de-l-obstruction-a-la-manifestation-de-la-verite_5041553_3212.html

Bakare-Yusuf, Bibi, Archival Fever, Dipsaus podcast, 30 December 2018 (accessed 7 February 2019).

https://www.dipsaus.org/exclusivesposts/2018/12/29/ihbijoa397wfc 7xsghodvlr216wlvn

Bat, Jean-Pierre, “Les Archives de l'AEF”, Afrique \& Histoire 1, no. 7 (2009), 301-11.

Blouin, Francis X. Jr and Rosenberg, William G. (eds), Archives, Documentation, and Institutions of Social Memory (Ann Arbor: The University of Michigan Press, 2005).

Breckenridge, Keith, "The Politics of the Parallel Archive: Digital Imperialism and the Future of Record-Keeping in the Age of Digital Reproduction", Journal of Southern African Studies, 40 (2014), 499-519.

Burton, Antoinette M., Archive Stories: Facts, Fictions, and the Writing of History (Durham, N.C.: Duke University Press, 2005).

Busia, Abena P. A., "Creating the Archive of African Women's Writing: Reflecting on Feminism, Epistemology, and the Women Writing Africa Project," Meridians 17 (2) (November 2018), 233-245.

Butterworth, Jody, "Saving Archives through Digitisation: Reflections on Endangered Archives Programme in Africa”, SCOLMA, 2017, 2-14.

Caswell, M. L., “'The Archive' Is Not an Archives: On Acknowledging the Intellectual Contributions of Archival Studies", Reconstruction: Studies in Contemporary Cultures, 16.1 (2016), p. $11<$ https://escholarship.org/uc/item/7bn4v1fk $>$ [accessed 13 June 2019]. 
Cook, Terry, "Archival science and postmodernism: new formulations for old concepts," Archival Science 1-1 (2001), 3-24.

Delva, Jean-Pierre, “Un autre regard sur les archives en Afrique”, Comma, 2015 (2016), 113118.

Derrida, Jacques [trans. by Eric Prenowitz], Archive Fever: A Freudian Impression, (Chicago: University of Chicago Press, 1996).

El-Malik, Shiera S. and Kamola, Isaac. A (eds), Politics of African Anticolonial Archives (London, New York: Rowman \& Littlefield, 2017).

El-Malik, Shiera S., and Isaac A. Kamola (eds.), Politics of African Anticolonial Archive (London: Rowman \& Littlefield, 2017).

Foucault, Michel, The Archeology of Knowledge (London: Tavistock, 1972).

Hardiman, Rachel, “En Mal d'archive: Postmodernist Theory and Record Keeping," Journal of the Society of Archivists 30, 1 (April 2009), 27-44.

Hiribarren, Vincent. "Hiding the Colonial Past, A Comparison of European Archival Policies". in James Lowry (ed.) Displaced Archives (London: Routledge, 2017), 74-85.

Imorou, Abdoulaye, “Thiaroye, Oradour-sur-Glane et les défis d'une mémoire partagée. Une lecture croisée de Camp Thiaroye et du Vieux Fusil." Études littéraires africaines, 40 (2015), $61-76$.

Isaacman, Allen, Premesh Lalu, and Thomas Nygren, "Digitization, History, and the Making of a Postcolonial Archive of Southern African Liberation Struggles the Aluka Project", Africa Today, 52 (2005), 55-77.

Kargbo, John Abdul, “The Connection between Good Governance and Record Keeping: The Sierra Leone Experience", Journal of The Society of Archivists, 30 (2009), 249-60. 
Kim, Katherine, “'Archives have never been neutral': An NDSA interview with Jarrett Drake”, DLF, 15 February 2017 (accessed 7 February 2019). https://www.diglib.org/archives-havenever-been-neutral-an-ndsa-interview-with-jarrett-drake/

Lagae, John, "From 'Patrimoine partagé' to 'whose heritage'? Critical Reflections on colonial built heritage in the city of Lubumbashi, Democratic Republic of the Congo", Afrika Focus 21-1 (2008), 11-30.

Le Lay, Maëline, “Performer l'archive pour réécrire l'histoire: l'exposition Congo Far West au Musée royal de l'Afrique centrale de Tervuren", In: Maëline Le Lay, Dominique Malaquais and Nadine Siegert (eds), Archive (re)mix. Vues d'Afrique (Paris: Presses Universitaires de Rennes, 2015), 107-123.

Limb, Peter, 'The Digitization of Africa', Africa Today, 52, 2 (2005), 3-19.

Limb, Peter, "The Politics of Digital "Reform and Revolution" towards Mainstreaming and African Control of African Digitisation', Innovation, 34, 1 (2007), 18-27.

Lowry, James (ed.) Displaced Archives (London: Routledge, 2017).

Martino, Enrique, "Open Sourcing the Colonial Archive - A Digital Montage of the History of Fernando Pó and the Bight of Biafra", History in Africa, 14 (2014), 387-415.

Mawani, Renisa, "Archival Legal History. Towards the Ocean as Archive," in: Markus D. Dubber and Christopher Tomlins (eds) Oxford Handbook of Legal History (Oxford: Oxford University Press, 2018), 291-310.

Mbaye, Ousmane, “Le CAOM: Un Centre d'archives Partagées?” Afrique \& Histoire 1-7 (2009), 291-299.

Mnjama, Nathan, and James Lowry. "A Proposal for Action on African Archives in Europe”, in James Lowry (ed.) Displaced Archives (London: Routledge, 2017), 101-113.

Moure, Martin, “Thiaroye 1944. Histoire et mémoire d'un massacre”, Africa4, Libération, 16 $\begin{array}{lllll}\text { August } & 2017 & \text { (accessed } & 7 & \text { February }\end{array}$ 
http://libeafrica4.blogs.liberation.fr/2017/08/16/thiaroye-1944-histoire-et-memoire-dun-

$\underline{\text { massacre/ }}$

Muller, Samuel, Feith Johan, A., Fruin, Robert, Manual for the Arrangement and description of Archives (New York: H.W. Wilson 1940).

Ndeshi Namhila, Ellen, "Archives of Anti-Colonial Resistance and the Liberation Struggle (AACRLS): An integrated programme to fill the colonial gaps in the archival record of Namibia", Journal for Studies in Humanities and Social Sciences 4(1-2) (2015), 168-178.

Ndeshi Namhila, Ellen, "Content and use of colonial archives: an under-researched issue", Archival Science 16 (2016), 111-123

Paprikka, Jussi, "Archival media theory. An introduction to Wolfgang Ernst's media archaeology”, in: Wolfgang Ernst Digital memory and the archives. (Minneapolis, London: University of Minnesota Press, 2013).

Potin, Yann, ’Intervention de Yann Potin", Gazette des archives, 225 (2012), 49-53.

Premesh, Lalu, “The Virtual Stampede for Africa: Digitisation, Postcoloniality and Archives of the Liberation Struggles in Southern Africa”, Innovation, 34 (2007), 28-44

Ryan, Deirdre, "Aluka: Digitization from Maputo to Timbuktu”, OCLC Systems \& Services, 26 (2010), 29-38.

Shepard, Todd, “'Of Sovereignty': Disputed Archives, 'Wholly Modern’ Archives, and the PostDecolonization French and Algerian Republics, 1962-2012”, American Historical Review 120, no. 3 (June 2015), 869-883.

Shringarpure, Bhakti, "Africa and the Digital Savior Complex", Journal of African Cultural Studies, 0 (2018), 1-17.

Stoler, Ann Laura, "Colonial Archives and the Arts of Governance: On the Content in the Form”, in: Francis X Blouin and William G Rosenberg (eds.), Archives, Documentation, and 
Institutions of Social Memory Essays from the Sawyer Seminar (Ann Arbor: University of Michigan Press, 2007), 267-279.

Taylor, Edgar, Ashley Rockenbach, and Natalie Bond, "Archives and the Past: Cataloguing and Digitisation in Uganda's Archives", in: Terry Barringer and Marion Wallace (eds.), Dis/Connects: African Studies in the Digital Age, (Leiden: Brill, 2014), 163-178.

Theimer, Kate, “A Distinction Worth Exploring: 'Archive' and 'Digital Historical Representations"”, Journal of Digital Humanities, 2014 (accessed 20 December 2018). http://journalofdigitalhumanities.org/3-2/a-distinction-worth-exploring-archives-and-digital$\underline{\text { historical-representations/ }}$

Trouillard, Stéphanie, "Massacre de Thiaroye: 70 ans après, les zones d'ombre demeurent," France24.com, 1 December 2014 (accessed $7 \quad$ February 2019). https://www.france24.com/fr/20141128-massacre-thiaroye-commemoration-senegal-dakar$\underline{\text { tirailleurs-armee-france-polemique-historien }}$ 